\title{
Bitter Taste Receptors as Regulators of Abdominal Muscles Contraction
}

\author{
P. ZAGORCHEV ${ }^{1,4}$, G. V. PETKOV ${ }^{2}$, H. S. GAGOV ${ }^{3}$ \\ ${ }^{1}$ Department of Biophysics, Faculty of Pharmacy, Medical University-Plovdiv, Plovdiv, Bulgaria, \\ ${ }^{2}$ Department of Pharmaceutical Sciences, College of Pharmacy, University of Tennessee Health \\ Science Center, Memphis, Tennessee, USA, ${ }^{3}$ Faculty of Biology, Sofia University St. Kliment \\ Ohridski, Sofia, Bulgaria, ${ }^{4}$ Institute of Neurobiology, Bulgarian Academy of Sciences, Sofia, \\ Bulgaria
}

Received February 28, 2019

Accepted July 16, 2019

Epub Ahead of Print October 25, 2019

\section{Summary}

Bitter taste receptors (TAS2R) are expressed in many non-sensor tissues including skeletal muscles but their function remains unexplored. The aim of this study is to investigate the role of TAS2R in rat abdominal skeletal muscles contractions using denatonium, a TAS2R agonist. Low concentration of denatonium $(0.01 \mathrm{mmol} / \mathrm{l})$ caused a significant decrease of amplitudes of the electrical field stimulation (EFS)-induced contractions in abdominal skeletal muscles preparations in vitro. This inhibitory effect was significantly reduced when the preparations were preincubated with gentamicin $(0.02 \mathrm{mmol} / \mathrm{l})$ used as a non-specific inhibitor of $\mathrm{IP}_{3}$ formation or with $\mathrm{BaCl}_{2}(0.03 \mathrm{mmol} / \mathrm{l})$ applied to block the inward-rectifier potassium current. All experiments were performed in the presence of pipecuronium in order to block the nerve stimulation of the contractions. The data obtained suggest that denatonium decreases the force of rat abdominal muscles contractions mainly via activation of TAS2R, phosphatidylinositol 4,5-biphosphate and its downstream signal metabolites.

\section{Key words}

Skeletal muscle - Taste receptors • Electric field stimulation • $\mathrm{PIP}_{2} \bullet \mathrm{IP}_{3} \bullet$ Relaxation

\section{Corresponding author}

H. Gagov, Faculty of Biology, Sofia University St. Kliment Ohridski, 8 Dragan Tzankov blvd. 8, Sofia, 1164 Bulgaria. E-mail: hgagov@abv.bg

\section{Introduction}

Sweet, umami and bitter taste receptors are widely expressed in non-taste sensory organs. Bitter taste receptors (TAS2R) are involved in the regulation of the physiological processes such as airway smooth muscle cell relaxation and bronchodilation, the secretion of the gastro-intestinal tract, artery relaxation, as well as in the modulation of nervous and immune systems (for review Dalesio et al. 2018). These influences are supposed to be related to TAS2R signal pathway which activates G-protein, phospholipase C (PLC), protein kinase C (PKC) and $\mathrm{IP}_{3}$-induced $\mathrm{Ca}^{2+}$ release (IICR) in non-taste sensory tissues (Avau et al. 2015, Dalesio et al. 2018). As a result of this stimulation, cytoplasmic $\mathrm{Ca}^{2+}$ concentration increases and several protein targets of PKC change their activities. However, the effects of TAS2R activation in skeletal muscles remain unclear. The aim of this study is to investigate the effect of denatonium, an agonist of TAS2R, on electrical field stimulation (EFS)-induced abdominal skeletal muscles contractions and their dependence on phosphatidylinositol 4,5-bisphosphate $\left(\mathrm{PIP}_{2}\right)$ and its break down. The role of inward-rectifier potassium (Kir) channels on TAS2R-induced effect was also studied.

\section{Materials and Methods}

The experiments were approved by the 
Bulgarian Food Safety Agency and the Ethics Committee of the Medical University of Plovdiv, Bulgaria (approval nos. 87/9.01.2014 and 5/29.09.2016 respectively). Male Wistar rat transversus abdominis muscles strips were isometrically fixed as previously described (Zagorchev et al. 2016). During a period of $20 \mathrm{~min}$ the muscle activity was elicited by unipolar EFS used as a control and analysed (Zagorchev et al., 2018). EFS were repeated, square-wave multipulses of supramaximal intensity, $0.5 \mathrm{~ms}$ in duration applied at frequency of $5 \mathrm{~Hz}$ and $50 \mathrm{~Hz}$ for $3 \mathrm{~s}$ followed by a $7 \mathrm{~s}$ pause. After this, denatonium $10^{-5} \mathrm{~mol} / \mathrm{l}$, gentamicin $2.10^{-5} \mathrm{~mol} / \mathrm{l}$, gentamicin $2.10^{-5} \mathrm{~mol} / \mathrm{l}$ and denatonium $10^{-5} \mathrm{~mol} / 1, \mathrm{BaCl}_{2}$ $3.10^{-5} \mathrm{~mol} / 1$ or $\mathrm{BaCl}_{2} 3.10^{-5} \mathrm{~mol} / 1$ and denatonium $10^{-5} \mathrm{~mol} / \mathrm{l}$ were added to the organ baths. All experiments were conducted in the presence of $10^{-5} \mathrm{~mol} / 1$ pipecuronium to block the nerve stimulation of the muscles (Youssef et al. 1993). For a statistical analysis, SPSS.15 (Chicago, IL, USA) was employed. All data are expressed as mean \pm SEM after verifying the normality one-way analysis of variance (ANOVA), Bonferroni Multiple Comparison Test the Paired samples t-test. The number of tested muscle strips is indicated by $n$. Results were considered as statistically significant at $p<0.05$.

\section{Results}

EFS-evoked $(5 \mathrm{~Hz})$ single contractions of rat transversus abdominis muscles preparations in vitro maintain stable but slightly declining amplitudes in the presence of pipecuronium, which was added to block the nerve stimulation of nicotinic acetylcholine receptor (nAChR, time control). Thus 1 min after drug application it was $5.2 \pm 0.5 \mathrm{mN}$, after $5 \mathrm{~min}-4.7 \pm 0.5 \mathrm{mN}$ and after $15 \mathrm{~min}-4.1 \pm 0.4 \mathrm{mN}$ (Fig. $1 \mathrm{~A}, \mathrm{~B}$ and $\mathrm{C}$, left column and Fig. 2, left panel, ж). The same event but less pronounced was observed in $50 \mathrm{~Hz}$ EFS-evoked tetanic contractions (Fig. 1D and Fig. 2, right panel, ж). The addition of denatonium at a concentration of $10^{-5} \mathrm{~mol} / 1$ induced a significant decrease $(\mathrm{p}<0.05, \mathrm{n}=12)$ of the force of single contractions after $5 \mathrm{~min}$ to $1.7 \pm 0.6 \mathrm{mN}$ and almost complete inhibition after $15 \mathrm{~min}(0.3 \pm 0.1 \mathrm{mN})$ along with a large decrease $(\mathrm{p}<0.05, \mathrm{n}=12)$ of tetanic contractions after $15 \mathrm{~min}(2.3 \pm 0.5 \mathrm{mN})($ Fig. $2 \mathrm{~A}, \bullet)$. The inhibition of the contraction force was faster when $5.10^{-5} \mathrm{~mol} / \mathrm{l}$ denatonium was used (data not shown). A low concentration of gentamicin $\left(2.10^{-5} \mathrm{~mol} / \mathrm{l}\right)$ was applied into the bath to suppress selectively $\mathrm{IP}_{3}$ generation. This treatment also reduced the force of single and tetanic EFS-induced contractions but with a constant potency during the whole studied time interval (Fig. 1, Fig. 2A, - ). In the presence of simultaneously added $2.10^{-5} \mathrm{~mol} / 1$ gentamicin and $10^{-5} \mathrm{~mol} / 1$ denatonium (Fig. 1, Fig. 2A, $\diamond$ ) a further decrease in the amplitudes of the contraction force was observed but the effect of denatonium was less pronounced as compared to the single contractions $(\mathrm{p}<0.05, \mathrm{n}=12)$. Thus, the amplitudes of contractions after $5 \mathrm{~min}$ were $3.3 \pm 0.3 \mathrm{mN}$, after $10 \mathrm{~min}$ - $3.0 \pm 0.4 \mathrm{mN}$, after $15 \mathrm{~min}-2.6 \pm 0.3 \mathrm{mN}$ and at $20 \mathrm{~min}$ - $2.3 \pm 0.3 \mathrm{mN}$. For tetanic contractions, the denatonium suppression of the force of contraction in the presence of gentamicin was weaker: after $10 \mathrm{~min}$ it was $5.3 \pm 0.5 \mathrm{mN}$, after $15 \mathrm{~min}-5.0 \pm 0.5 \mathrm{mN}$ and after $20 \mathrm{~min}-4.9 \pm 0.4 \mathrm{mN}$.

Next, we applied $\mathrm{BaCl}_{2}$ to inhibit Kir channels. In the presence of $0.03 \mathrm{mmol} / 1 \mathrm{Ba}^{2+}$ the maximal amplitudes of single contractions slightly declined after 5 min $\mathrm{BaCl}_{2}$ application to $4.3 \pm 0.6 \mathrm{mN}$, to $3.9 \pm 0.5 \mathrm{mN}$ after $10 \mathrm{~min}$, to $3.6 \pm 0.4 \mathrm{mN}$ after $15 \mathrm{~min}$ and to $3.5 \pm 0.4 \mathrm{mN}$ after $20 \mathrm{~min}$ (Fig. 2B, left panel, $\mathbf{}$ ). In the presence of both $0.03 \mathrm{mmol} / 1 \mathrm{BaCl}_{2}$ and $0.01 \mathrm{mmol} / \mathrm{l}$ denatonium, the amplitudes of contractions were further reduced to $3.6 \pm 0.4 \mathrm{mN}, 3.3 \pm 0.5 \mathrm{mN}, 3.0 \pm 0.5 \mathrm{mN}$ and to $2.9 \pm 0.4 \mathrm{mN}$ after the same time intervals. Similar results of $\mathrm{Ba}^{2+}$ or $\mathrm{Ba}^{2+}$ and denatonium were obtained on the tetanic contractions.

All these data indicate that low concentrations of gentamicin or $\mathrm{Ba}^{2+}$ substantially reduce the inhibitory effect of denatonium on the EFS-induced single and tetanic contractions of abdominal skeletal muscles preparations in vitro.

\section{Discussion}

To the best of our knowledge this is the first report on denatonium-dependent regulation of skeletal muscle function. The effective low concentration of denatonium suggests a selective denatonium-TAS2R interaction followed by a G-protein-dependent activation of PLC that breaks down $\mathrm{PIP}_{2}$, into $\mathrm{IP}_{3}$ and diacylglycerol (DAG), as well as weakens the EFS-induced contractions. This hypothesis is supported by the significantly suppressed effect of denatonium in the presence of gentamicin, the latter used to inhibit $\mathrm{IP}_{3}$-formation (Touchberry et al. 2014). It is known that application of higher concentrations of gentamicin can decrease the motor neuron stimulation of contraction because it is a competitive inhibitor of nAChR (Amici et al. 2005) and thus it reduces the amplitudes of skeletal muscle 
contractions. However, under our experimental conditions, neuronal ACh mediation was eliminated and EFS stimulations excited only the skeletal muscles. Additionally, the low concentration of gentamicin greatly increased rather than suppressed the force of contractions in the presence of denatonium. Therefore, we assume that such a side effect is successfully avoided and almost a 'pure' influence of gentamicin on $\mathrm{PIP}_{2} / \mathrm{IP}_{3} / \mathrm{DAG}$ signaling is achieved. Also, the effective low concentration of gentamicin suggests that the influence of TAS2R activation on $\mathrm{PIP}_{2}$ metabolism is not completely eliminated and this could be a reason for the partial block of denatonium-induced relaxation.

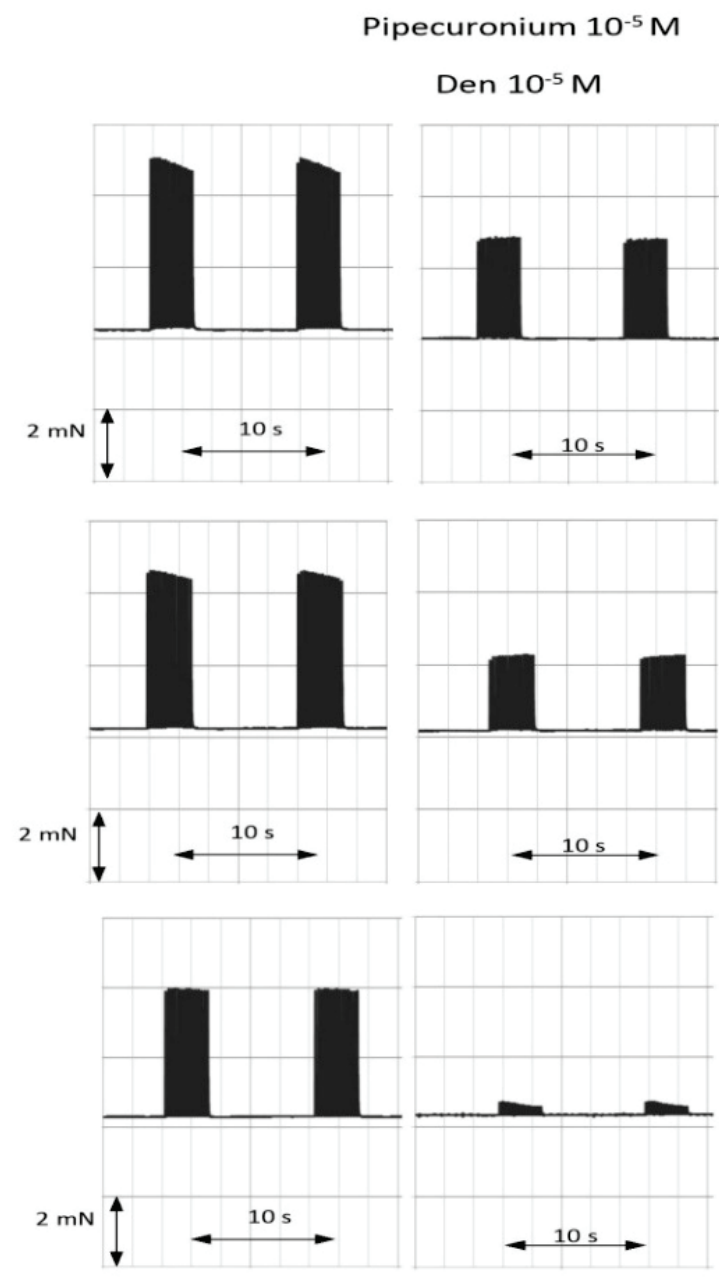

EFS: $0.5 \mathrm{~ms} ; 5 \mathrm{~Hz} ; 45 \mathrm{~V}$

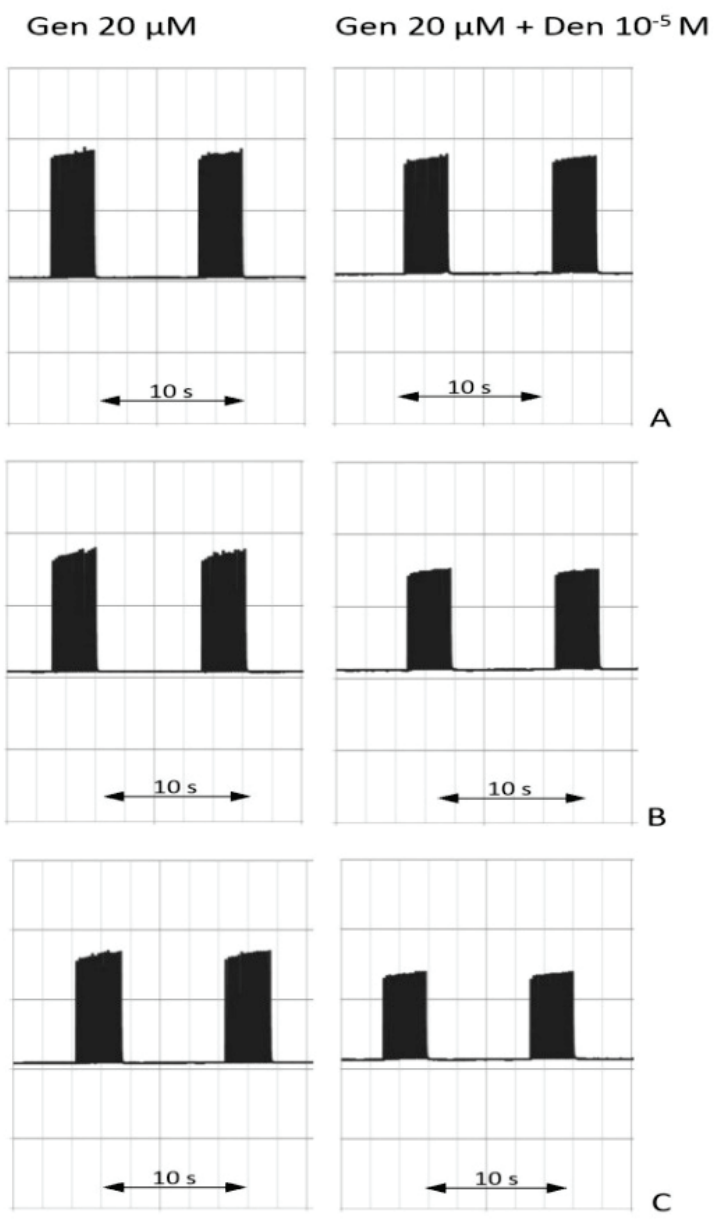

Pipecuronium $10^{-5} \mathrm{M}$

EFS: $0.5 \mathrm{~ms} ; 50 \mathrm{~Hz} ; 45 \mathrm{~V}$

Den $10^{-5} \mathrm{M}$

Gen $20 \mu \mathrm{M}$

Gen $20 \mu \mathrm{M}+$ Den $10^{-5} \mathrm{M}$
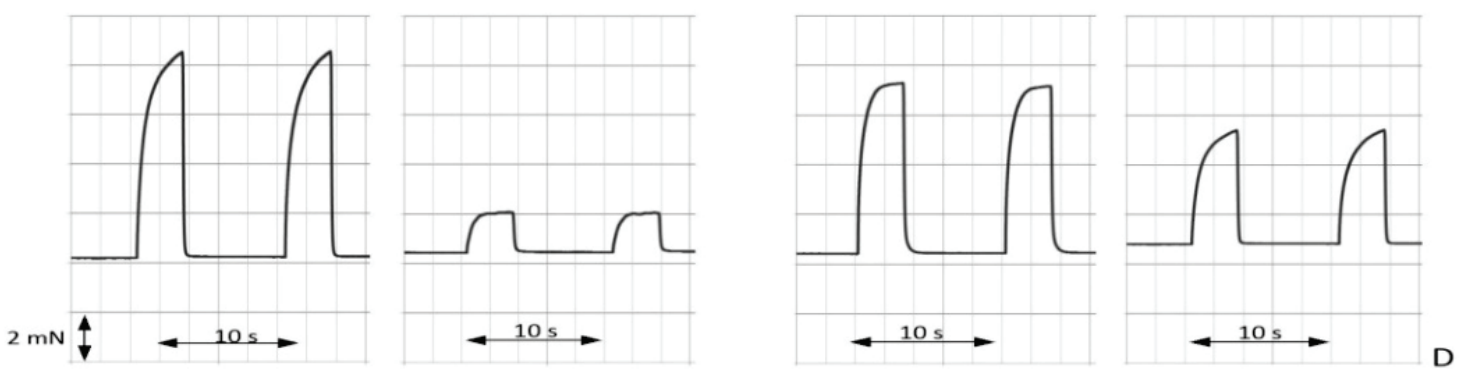

Fig. 1. Direct EFS-evoked contractions of $m$. transversus abdominis preparations in vitro in the presence of $10^{-5}$ mol/l pipecuronium and after the addition of $10^{-5} \mathrm{~mol} / \mathrm{l}$ denatonium (Den $10^{-5} \mathrm{M}$ ), of $2.10^{-5} \mathrm{~mol} / \mathrm{l}$ gentamicin $\left(\mathrm{Gen} 20 \mu \mathrm{M}\right.$ ) and of $10^{-5} \mathrm{~mol} / \mathrm{l}$ denatonium and $2.10^{-5} \mathrm{~mol} / \mathrm{l}$ gentamicin (Gen $20 \mu \mathrm{M}+$ Den $10^{-5} \mathrm{M}$ ). A) after $1 \mathrm{~min}, \mathbf{B}$ ) after $5 \mathrm{~min}$ and C) after $15 \mathrm{~min}$, all stimulated with EFS - $0.5 \mathrm{ms,}$ $5 \mathrm{~Hz}, 45 \mathrm{~V}$, D) $15 \mathrm{~min}$ after EFS with duration $0.5 \mathrm{~ms}, 50 \mathrm{~Hz}, 45 \mathrm{~V}$. 

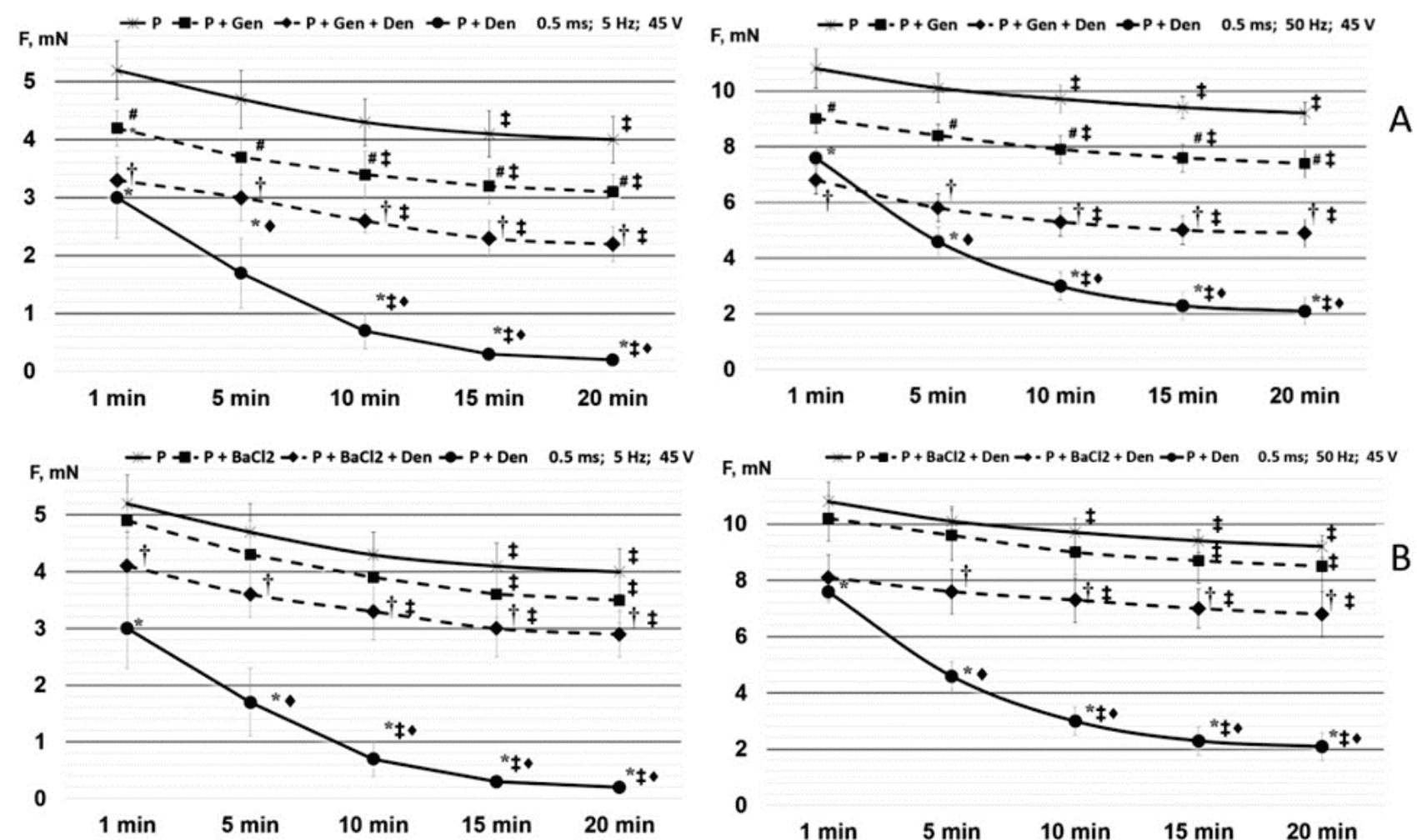

Fig. 2. Time dependence of contraction force by direct EFS stimulation: $0.5 \mathrm{~ms}, 5 \mathrm{~Hz}, 45 \mathrm{~V}$ - left and $0.5 \mathrm{~ms}, 50 \mathrm{~Hz}$, $45 \mathrm{~V}-$ right. A) The curves represent the force in $\mathrm{mN}$ in the presence of $10^{-5} \mathrm{~mol} / \mathrm{l}$ pipecuronium $(\mathrm{P}, \boldsymbol{*})$ for a time control, of $10^{-5} \mathrm{~mol} / \mathrm{l}$ pipecuronium and $2.10^{-5} \mathrm{~mol} / \mathrm{l}$ gentamicin $(\mathrm{P}+\mathrm{Gen}, \mathbf{a})$, of $10^{-5} \mathrm{~mol} / \mathrm{l}$ pipecuronium, $2.10^{-5} \mathrm{~mol} / \mathrm{l}$ gentamicin and $10^{-5} \mathrm{~mol} / \mathrm{l}$ denatonium $(\mathrm{P}+\mathrm{Gen}+\mathrm{Den}, \bullet)$ and of $10^{-5} \mathrm{~mol} / \mathrm{l}$ pipecuronium and denatonium $(P+$ Den, $\bullet), \neq p<0.05, n=12$ vs effect on $1 \mathrm{~min}$ of the following measurements after 5, 10, 15 и 20 min, \# $\mathrm{p}<0.05$ gentamicin vs time control, * $\mathrm{p}<0.05, \mathrm{n}=12$ denatonium vs time control, $+\mathrm{p}<0.05 \mathrm{n}=12$ for denatonium vs gentamicin and $\bullet \mathrm{p}<0.05, \mathrm{n}=12$ for denatonium vs denatonium and gentamicin. B) The curves represent the force in $\mathrm{mN}$ in the presence of $10^{-5} \mathrm{~mol} / \mathrm{l}$ pipecuronium $\left(\mathrm{P}\right.$, ж) for time control, of $10^{-5} \mathrm{~mol} / / \mathrm{l}$ pipecuronium and $3.10^{-5} \mathrm{~mol} / \mathrm{l} \mathrm{BaCl} 2\left(\mathrm{P}+\mathrm{BaCl}_{2}, \mathbf{\square}\right)$, of $10^{-5} \mathrm{~mol} / \mathrm{l}$ pipecuronium, $3.10^{-5} \mathrm{~mol} / \mathrm{l} \mathrm{BaCl} 2$ and $10^{-5} \mathrm{~mol} / \mathrm{l}$ denatonium $\left(\mathrm{P}+\mathrm{BaCl}_{2}+\mathrm{Den}, \downarrow\right)$ and of $10^{-5} \mathrm{~mol} / \mathrm{l}$ pipecuronium and denatonium $(P+$ Den, $\bullet), \neq p<0.05, n=12$ vs effect on 1 min of the following measurements after $5,10,15$ and $20 \mathrm{~min}, \# p<0.05$ $\mathrm{BaCl}_{2}$ vs time control, * $\mathrm{p}<0.05, \mathrm{n}=12$ denatonium vs time control, $+\mathrm{p}<0.05, \mathrm{n}=12$ for denatonium vs $\mathrm{BaCl}_{2}$ and $\bullet \mathrm{p}<0.05, \mathrm{n}=12$ for denatonium vs denatonium and $\mathrm{BaCl}_{2}$.

Another set of experiments targeted Kir channels. It is generally accepted that Kir2.1 and Kir2.2 channels are the prevalent forms of Kir channels in skeletal muscles (DiFranco et al. 2015). They are present either on the surface (about $30 \%$ ) or in T-tubules (about $70 \%$ ) of fibres (DiFranco et al. 2015). Kir channels play a crucial role in skeletal muscle excitability by keeping the extracellular concentration of $\mathrm{K}^{+}$low and thus the resting membrane potential at optimal value (DiFranco et al. 2015). Kir2.x channels are very important for keeping the physiological $\mathrm{K}^{+}$gradients, especially in T-tubules, because of the restricted intra T-tubular space that can be easily saturated by $\mathrm{K}^{+}$when $\mathrm{K}^{+}$return (influx) is disturbed. The latter will ultimately lead to membrane depolarization and will complicate the excitationcontraction coupling in the skeletal muscle fibres. Additionally, it is known that Kir2.1 channels has several $\mathrm{PIP}_{2}$ binding sites which directly activate the channels (Soom et al. 2001). That is why, we tested Kir channel as possible participants in denatonium induced signaling using low concentration of $\mathrm{BaCl}_{2}$ to block the channel. Similarly to gentamicin, barium ions reduced the effect of denatonium on the amplitudes of the studied contractions. These results suggest a link between Kir channels and TAS2R-induced reduction of amplitudes of single and tetanic contractions of rat abdominal muscles. Our data do not rule out the involvement of other cellular targets of the denatonium signal transduction pathway with significant effect on EFS-induced contractions.

The novel finding of our research is that denatonium regulates the contractility of rat abdominal skeletal muscle via TAS2R, PIP 2 and its metabolites. This denatonium effect depends on the availability of Kir channels. Additionally, our study outlines the described preparations as an appropriate object of diverse physiological and pharmacological studies on TAS2R/PIP $2 / \mathrm{IP}_{3}+\mathrm{DAG}$ signaling in skeletal muscles. The functional significance of IICR in them is still not very 
clear (Filip et al. 2019a, b), although all three $\mathrm{IP}_{3}$ receptor subtypes are expressed there, two of them ubiquitously (Santulli et al. 2017).

\section{Conflict of Interest}

There is no conflict of interest.

\section{Acknowledgements}

This work was supported by the Bulgarian National Research Fund [grant number: DN 11/15 /18.12. 2017], NATO Science for Peace and Security Programme [grant number: NATO SPS MYP G5266] and NIH R01DK106964 grant to Georgi V. Petkov.

\section{References}

AMICI M, EUSEBI F, MILEDI R: Effects of the antibiotic gentamicin on nicotinic acetylcholine receptors. Neuropharmacol 49: 627-637, 2005.

AVAU B, ROTONDO A, THIJS T, ANDREWS CN, JANSSEN P, TACK J, DEPOORTERE I: Targeting extra-oral bitter taste receptors modulates gastrointestinal motility with effects on satiation. Sci Rep 5: 15985, 2015.

DALESIO NM, BARRETO ORTIZ SF, PLUZNICK JL, BERKOWITZ DE: Olfactory, Taste, and Photo Sensory Receptors in Non-sensory Organs: It Just Makes Sense. Front Physiol 9: 1673, 2018.

DIFRANCO M, YU C, QUIÑONEZ M, VERGARA JL: Inward rectifier potassium currents in mammalian skeletal muscle fibres. $J$ Physiol 593: 1213-1238, 2015.

FILIP S, MOKRÝ J, FOROSTYAK O, DAYANITHI G: The extracellular matrix and $\mathrm{Ca}^{2+}$ signaling mechanisms. Physiol Res 68: 161-170, 2019a.

FILIP S, MOKRÝ J, FOROSTYAK O, DAYANITHI G: Analysis of $\mathrm{Ca}^{2+}$ signaling mechanisms - our experience on the intercellular communication in muscle remodeling. Physiol Res 68: 325-328, $2019 \mathrm{~b}$.

SANTULLI G, LEWIS D, DES GEORGES A, MARKS AR, FRANK J: Intracellular calcium release channels: an update. J Physiol 595: 3041-3051, 2017.

SOOM M, SCHÖNHERR R, KUBO Y, KIRSCH C, KLINGER R, HEINEMANN SH: Multiple PIP2 binding sites in Kir2.1 inwardly rectifying potassium channels. FEBS Lett 490: 49-53, 2001.

TOUCHBERRY CD, SILSWAL N, TCHIKRIZOV V, ELMORE CJ, SRINIVAS S, AKTHAR AS, SWAN HK, WETMORE LA, WACKER MJ: Cardiac thromboxane A2 receptor activation does not directly induce cardiomyocyte hypertrophy but does cause cell death that is prevented with gentamicin and 2-APB. BMC Pharmacol Toxicol 15: 73, 2014.

YOUSSEF SA, AFIFI NA, RAMADAN A, IBRAHIM EI: Comparative haemodynamic alterations induced by pipecuronium and pancuronium. Dtsch Tierarztl Wochenschr 100: 316-318, 1993.

ZAGORCHEV P, APOSTOLOVA E, KOKOVA V, PEYCHEV L: Activation of KCNQ channels located on the skeletal muscle membrane by retigabine and its influence on the maximal muscle force in rat muscle strips. Naunyn-Schmiedeberg's Arch Pharmacol 389: 439-446, 2016.

ZAGORCHEV P, KOKOVA V, APOSTOLOVA E, PEYCHEV L: Possible role of 18-kDa translocator protein (TSPO) in etifoxine-induced reduction of direct twitch responses in isolated rat nerve-skeletal muscle preparations. Trop J Pharm Res 17: 1309-1315, 2018. 